\title{
UDC 327(477:4)
}

DOI: $10.24919 / 2519-058 x .14 .197189$

\section{Lesya ALEXIYEVETS}

PhD hab. (History), Professor, Honoured Worker of Science and Technology of Ukraine, Deputy Dean of History Department on Scientific Work and International Cooperation, Volodymyr Hnatyuk National Pedagogical University in Ternopil, 2 M. Kryvonis Street, Ternopil, Ukraine, postal code 46027 (Imalex@tnpu.edu.ua)

ORCID: https://orcid.org/0000-0002-0030-3314

ReseacherID: https://publons.com/researcher/3328065/lesya-alexiyevets/

\section{Mykola ALEXIYEVETS}

PhD hab. (History), Professor, Honoured Education Worker of Ukraine, Professor of the World History and Religious Study Chair, Volodymyr Hnatyuk National Pedagogical University in Ternopil, 2 M. Kryvonis Street, Ternopil, Ukraine, postal code 46027 (malexiyevets@tnpu.edu.ua)

ORCID: https://orcid.org/0000-0001-6128-0438

ReseacherID: https://publons.com/researcher/3328103/mykola-alexiyevets/

\section{Леся АЛЕКСІЕВЕЦЬ}

доктор історичних наук, професор, заслужений діяч науки і техніки Украӥни, заступник декана історичного факультету з наукової роботи і міжнародного співробітництва Тернопільського національного педагогічного університету ім. Володимира Гнатюка, вул. М. Кривоноса, 2, Тернопіль, Україна, індекс 46027 (lmalex@tпри.еdи.иа)

\section{Микола АЛЕКСІЕВЕЦЬ}

доктор історичних наук, професор, заслужений працівник освіти Украӥни, професор кафедри всесвітньої історії та релігієзнавства Тернопільського національного педагогічного університету ім. Володимира Гнатюка, вул. М. Кривоноса, 2, Тернопіль, Украӥна, індекс 46027 (malexiyevets@tпри.edu.иа)

Бібліографічний опис статті: Alexiyevets, L. \& Alexiyevets, M. (2020). Ukraine - the NATO: mutual relations and partnerships main stages. Skhidnoievpropeiskyi Istorychnyi Visnyk [East European Historical Bulletin], 14, 175-189. doi: 10.24919/2519-058x.14.197189

\section{UKRAINE - THE NATO: MUTUAL RELATION AND PARTNERSHIPS MAIN STAGES}

\begin{abstract}
The aim of the research is to identify and analyse the main stages of Ukraine's relations with the North Atlantic Alliance by characterizing the milestones and optimizing the main parameters of interaction in the context of the latest geopolitical coordinates. The methodology of the research is based on the principles of objectivity and historicism, as well as general and specialized scientific methods and the interdisciplinary and systematic approaches application. The scientific novelty is that, for the first time in historiography, the author's periodization of Ukraine's relation with the NATO has been proposed. The Conclusions. The NATO-Ukraine relations have come a long way from the Special Partnership Charter, the Action Plan, the Intensified Dialogue on Membership, and others. documents that have generated significant versatile potential for the Euro-Atlantic choices.
\end{abstract}


The NATO and Ukraine have a long history of mutual relations, from multi-vector and neutrality to accelerated integration and constitutional consolidation of Ukraine's accession to the North Atlantic Treaty Organization. Characteristic of Ukraine-NATO cooperation is the process of its structural modernization and intensification of political dialogue in the political and military spheres. Under current conditions, the NATO-Ukraine relations play an important role in enhancing Ukraine's defense capability to counter the Russian aggression, will help strengthen national security, reform the armed forces by the NATO standards, and create the foundations for Ukraine's democratic development. Ukraine's further movement to the NATO appears to be an alternative in today's international and regional security environment. The acceleration of Ukraine's emergence as a full-fledged component of the Euro-Atlantic civilization and its promotion to the NATO membership depends on the political will of the new political generation and Ukrainian society.

Key words: Ukraine, The North Atlantic Treaty Organisation relations, partnership, present day, Euro-Atlantic activists.

\title{
УКРАЇНА - НАТО: ОСНОВНІ ЕТАПИ ВЗАЕМОВІДНОСИН ТА ПАРТНЕРСТВА СУЧАСНОСТІ
}

\begin{abstract}
Анотація. Мета дослідження - визначення та аналіз основних етапів взаємовідносин Украӥни з Північноатлантичним альянсом шляхом характеристики рубіжних віх і оптимізації основних параметрів взаємодії у контексті новітніх геополітичних координат. Методологія праці спирається на принципи об 'єктивності та історизму, а також загально- та спеціальнонаукові методи і міждисциплінарний й системний підходи. Наукова новизна полягає у тому, що вперше в історіографії запропоновано авторську періодизацію стосунків Украӥни з НАТО сучасності. Висновки. Відносини України з НАТО пройшли складний шлях від Хартії про особливе партнерство, Плану дій, Інтенсифікованого діалогу з питань набуття членства та інших документів, у рамках яких напрачьовано значний різнобічний потенціал для здійснення свроатлантичного вибору. Україна та НАТО мають уже чималу історію взаємовідносин від багатовекторності й нейтральності до прискореної інтеграції $і$ конституційного закріплення вступу України в Організацію Північноатлантичного договору. Характерним для співробітництва Украӥни і НАТО є прочес його структурної модернізаиії та посилення політичного діалогу в політичній і воєнній сферах. У нинішніх умовах украйнсько-натовські відносини відіграють важливу роль у посиленні обороноздатності України для протидії агресії РФ, сприятимуть зміцненню наиіональної безпеки, реформуванню збройних сил за стандартами НАТО, створенню засад демократичного розвитку України. Подальший рух Украӥни в НАТО виглядає безальтернативним в умовах сучасної міжнародної та регіональної безпекової обстановки. Прискорення становлення України як повноправної складової євроатлантичної иивілізаиії та її просування до членства в НАТО залежить від політичної волі нової політичної генерації та українського суспільства.
\end{abstract}

Ключові слова: Україна, Організачія Північноатлантичного договору, взаємовідносини, партнерство, сучасність, активісти-свроатлантисти.

The Problem Statement. In the sphere of Ukraine's foreign policy activity, the national's interest priority is the establishment and further deepening of the development of strategic partnership relations with the North Atlantic Treaty Organization (NATO). In the face of contemporary threats to the territorial integrity and international isolation, which would have a fatal impact on the future of the Ukrainian state, its cooperation with the Alliance, which remains the most powerful collective security system in the world, is crucial to ensuring our country's defense capability. Harnessing the capabilities and practical assistance of the NATO member countries is helping to reform Ukraine's Armed Forces, the security and defense sector, and its industrial and defense sector to its standards. Annexation of the Crimea by the Russian Federation, the occupation of Donbass, war with Russia in the East of Ukraine. The conduct against our state, the so-called "hybrid war", the permanent process 
of exerting pressure on all spheres of life on the part of the Russian Federation, provided for cooperation and the NATO membership in the Constitution of Ukraine (02/02/2019). Taking into consideration the complexity of the issues outlined, according to the authors' view, it is necessary, first of all, to identify the main periods of relations with the Alliance, through which the problems of the evolution of dynamics and the establishment of their priorities and milestones should be identified. Such a methodological approach will allow a greater understanding of the importance of an in-depth study of the key stages of the NATO-Ukraine relationship, will help to understand the decisive directions and results of Ukraine's partnership with the North Atlantic Alliance, gaining special importance and a new perspective on finding a more effective and secure national security. Ukraine's further movement towards the NATO is an alternative in the current international and regional current security environment on the continent. The proposed work corresponds to both scientific and practical request for the Ukraine's Euro-Atlantic course implementation. The above-mentioned information actualizes the research and makes it extremely important and necessary.

The Analysis of Recent Researches. The historiography of the initial scientific problem is represented by a considerable mass of literature, which is divided into two main groups conditionally: general and special developments in the context of their consideration on the problem-chronological principle. The first group includes works on general nature, in which the identified problems are covered in general, in connection with the Ukraine's foreign policy activity disclosure in the new geopolitical conditions. There are numerous works of the Ukrainian scientists among them: O. Ivchenko (Ivchenko, 1997), A. Halchynskyi (Halchynskyi, 2002), I. Todorov (Todorov, 2006), L. Chekalenko (Chekalenko, 2011), S. Vidnyanskyi (Vidnyanskyi, 2011), A. Martynov (Martynov, 2015), L. Aleksiyevts and S. Pryidun (Aleksiyevts, Pryidun, 2012), A. Zlenko (Zlenko, 2009), M. Aleksiyevts and Y. Seko (Aleksiyevts, Seko, 2016). A numberof foreign scientists have dealt with the above-mentioned issue: E. Lucas (Lucas, 2009), Z. Brzezinski (Brzezinski, 2006), S. Huntington (Huntington, 2016), F. Fukuyama (Fukuyama, 2019) and the others. Their publications laid the theoretical and methodological foundations for an in-depth study of the problem.

The second group of literature on this topic includes the scientists' work, whose subject of the research deals with the formation and development of modern relations between Ukraine and the NATO, the impact of the Alliance on the process of ensuring the country's defense capabilities. There are the publications of T. Boyetskyi (Boyetskyi, 2006), S. George (George, 2006), O. Zuiko (Zuiko, 2006), S. Lepyavka, A. Mahomedov (Lepyavko, Mahomedov, 2018), V. Horbulin (Horbulin, 2009), L. Polyakov (Polyakov, 2007). O. Chernousenko (Chernousenko, 2003), A. Kudriachenko (Kudriachenko, 2009), H. Perepelytsia (Perepelytsia, 2009). S. Pryidun (Pryidun, 2017) and others. The problems of Ukraine's cooperation with the NATO, from simple cooperation to the legalization of the course for our country's accession to the Alliance as a priority area of the foreign policy activity in the security sphere, were considered in the collective works under the editorship of O. Soskin (Soskin, 2007; Soskin, 2008), H. Perepelytsya (Perepelytsya, 2002), O. Vlasyuk (Vlasyuk, 2008). E. Marchuk's work "Na Shlyakhy Do NATO" (Towards NATO) played the important role in the historiographical development of the topic (Marchuk, 2016), which contains his publications in the media on Ukraine's possible accession to the NATO from 1999 to 2016. Consideration concerning the problem's development state indicates a sufficiently high level of experience in the topic on European-Atlantic integration of Ukraine, the evolution of its relations with the Alliance in the historical context. However, the complicated current inter- 
national environment and the Russian threat of further aggression encourage researchers to discourse on the above-mentioned issues and to understand the peculiarities and priorities of Ukraine's engagement with the NATO in order to see ways to optimally measure the implementation of the Euro-Atlantic course of the state according to the latest developments. It should be noted that the qualitative changes in the historiography of Ukrainian-NATO relations make it possible to identify their new objective studies, to show the achievements and challenges to the declared tasks on the way of the Ukrainian state's accession to the North Atlantic Treaty Organization. Will Ukraine be able to use all opportunities and make the right choice under the current conditions? In the light of the 2019 presidential and parliamentary elections, this issue is becoming increasingly important and remains open.

The purpose of the article is to substantiate and characterize the main stages of the NATO-Ukraine cooperation and partnership based on setting their milestones in the context of the geopolitical requirements of today.

The Statement of the Basic Material. It is well known that history has always shown that the world has always undergone the way of forming small and large integration associations. It is worth noting that in the past, these were mainly power integration entities for the purpose of wars uniting disparate peoples under a single political, economic, civilizational and religious pretext. Nowadays globalization philosophy of the modern world shows that the main driving force of European-Atlantic integration is to ensure peace, stability and national security, and to protect the sovereignty of independent states, and to improve welfare. According to the authors, this is what guides the international integration unions' participants and organizations. It is no exception in this process that Ukraine has proclaimed since its first years of independence its Euro-Atlantic aspirations to integrate into the world systemic structures to protect national interests, secure security and territorial integrity. Today, in the absence of material and economic prosperity and uncertainty of domestic and foreign policy, the formation of the image of a stable, democratic Ukraine, the search for possible allies, cooperation with European-economic associations is of utmost importance for its national security, is a priority, and quite relevant . It should be noted that Ukraine views its own security as an integral part of the integral strategy of Euro-Atlantic security, seeking to build foreign policy activities taking into account the interests of foreign states and the inviolability of their borders.

Taking into consideration the methodological approach, it becomes clear that there is the urgent need for Ukraine to join the collective security system. According to authors' opinion, the Ukrainian state should become a member of international organizations that guarantee collective security, since it is difficult to resolve this issue on its own due tothe current conditions. The North Atlantic Treaty Organization could be such a Euro-Atlantic alliance, as one of the defining components of the international relations, a structure around which a new configuration of the Euro-Atlantic security system is formed, containing not only a military-political but also socio-economic and scientific-environmental dimension. Therefore, the enhanced cooperation, the gradual European-Atlantic integration and accession to the NATO meet the Ukraine's national needs and interests. The idea of Ukraine's Euro-Atlantic integration has deep historical roots. The Euro-Atlantic component prevails in Ukraine as a European state. Throughout history, Ukraine sought for Euro-Atlantic format society introduction to prove the effectiveness that the NATO member countries are confidently demonstrating.

It should be noted that Ukraine has a long history of relations with the North Atlantic Treaty Organization. After Ukrainian independence the relations with the NATO began im- 
mediately, and have not lost their relevance for almost thirty years. The relations'importance not only grow but also does not diminish over time. The following process is natural, because the cooperation with the NATO will promote the democratic society development, human rights and freedoms, ensure the national security and territorial integrity of the country. Despite the ambiguity of a public opinion on Ukraine's accession to the NATO, it has been working closely with it on a bilateral and multilateral basis, and has developed considerable versatile potential for further Euro-Atlantic choices. The NATO-Ukraine relations absorbed certain achievements of engagement and contradictory aspects, heated discussions, which arouse especially in the Ukrainian society, but they can be characterized as dynamic, evolving from multi-vector and non-bloc to accelerating the Euro-Atlantic integration and the most expansive legislation. The above-mentioned information requires deep understanding of the NATO-Ukraine relations, their specificities analysis, the problematic aspects' identification and the partnership's experience full implementation priorities and the relations' model reformatting in accordance with the new geopolitical requirements and challenges to take into account the cooperation's intensification possibilities on the way to Ukraine's accession to the North Atlantic Alliance.

As it was above-mentioned, in order to gain a deeper understanding of all the various aspects of the NATO-Ukraine relations, the authors believe that the milestones and the main stages of modern relations between them and their institutionalization should be identified. Hence, it is possible to trace the Ukraine-NATO relations origin and development history, to demonstrate a systematic vision of the benefits and mutually beneficial cooperation between Ukraine and the NATO in political, military, economic, geopolitical terms in accordance with the national interests and the requirements of the modern world system transformation and modernization civilization more thoroughly. While defining the major milestones in Ukraine's relations with the NATO, it should be noted that they have taken on a strategic partnership format, play an important role in enhancing peace and security in the EuroAtlantic area, and are characterized by varying tensions and dynamism. Undoubtedly, Ukraine's relations with the NATO have come a long way from the simplest forms of cooperation to deepening Euro-Atlantic integration, regulating it with a number of treaties and agreements adopted during the years of cooperation. Nowadays, in the face of the Russian aggression, both the Ukrainian leadership political will and the civic support level for the implementation of Ukraine's legislative course to join the NATO are increasing. Following the widespread approach in Ukrainian historiography introduced by numerous researches (S. Vidyanskyi, A. Martynov, Y. Makar, I. Todorov, M. Aleksievets, Y. Seko, S. Pryidun, etc.), the criteria for determining the main stages of establishing and implementing cooperation with the Alliance the dynamics of events, the complications of forms of cooperation to the requirements of time, the quantitative and qualitative changes in the course of internal and external factors interaction, the specific circumstances, the creation of institutional and legal support for the implementation of the European-Atlantic choice of Ukraine in the situation of the increased international tension and mutual search for ways to modernize in the national interest and to strengthen peace and stability on the continent

It should be noted that in recent years the process of the European-Atlantic integration of Ukraine has become dynamic and has undergone a significant transformation. Therefore, Ukraine's full accession to NATO should be preceded by its systematic exploration and analysis within the framework of the main milestones in the Ukrainian-NATO relations' formation and development, the proper scientific and informational support for this process. 
Given the nature of the Euro-Atlantic space geopolitical transformations, the changes caused by the new system of the international relations and the above-mentioned criteria for the Euro-Atlantic integration development in Ukraine, according to the authors, it is possible to distinguish the following stages: the first stage: 1991 - 1997; the second stage: 1998 - 2000; the third stage: 2001 - 2004; the forth stage: 2004 - 2009; and, finally, the fifth stage covers the following years 2010 - 2019. Chronologically, these periods are outlined schematically, as the historical and political events of the NATO-Ukraine relations emerge a bit later or several years earlier. In fact, the course of domestic and foreign policy processes in $1991-2019$ defined the basic principles of creating the author's concept of Ukraine and the North Atlantic Treaty Organization periodization relations.

The first stage of the NATO-Ukraine relations began in the early 1990-ies, after Ukrainian independence and since the state is considered to be a significant Alliance partner. Most national scholars believe that the first attempts to define the foundations of the EuroAtlantic aspirations were outlined in the Declaration of State Sovereignty, which proclaimed the course (then the USSR) "for Ukraine's direct participation in the pan-European process and European structures" (1990, Declaration). Further, the Euro-Atlantic vector of foreign policy activity is legally enshrined in the "Main Foreign Policy Areas of Ukraine" (July 2, 1993), a key document defining the main tasks for integration into international structures, in particular its membership in the European collective security system, which has become more active after the end of the Cold War. Dialogue and cooperation between Kyiv and Brussels developed after the first visit to Ukraine on February $22-23,1992$, inviting the country to participate in the Euro-Atlantic Partnership Council (EAPC) and subsequently to the Euro-Atlantic Partnership Council (EAPC, 1997). On May $3^{\text {rd }}, 1992$, Ukraine became an Associate Member in the NATO Parliamentary Assembly, represented by the Permanent Delegation of the Verkhovna Rada. On July 8, 1992, President of Ukraine L. Kravchuk made an official visit to the NATO Headquarters, during which it was emphasized that the establishment of European security structures on the basis of existing international alliances such as the NATO, the Euro-Atlantic Partnership Council (EAPC), etc., will guarantee the external national security conditions. Since then, active contacts with the NATO have begun. The relations developed further. On November 16, 1992, General D. Shalikashvili, Commander-in-Chief of the Armed Forces of Europe, made an official visit to Kyiv, and in 1993, the NATO Foreign Minister A. Zlenko visited the NATO Headquarters. The intensification of actions by Ukraine at the initial stage with the North Atlantic Treaty Organization contributed to the deepening of relations with it, which was welcomed by the two parties. Dozens of visits were conducted, which defined the theoretical and conceptual foundations and programmatic tasks of Ukraine's European integration policy.

However, according to the authors, the period from 1994 till 1997 should be emphasized as the most vital one in the development of relations between Ukraine and the NATO. 1994 should be considered the year of regular and permanent contacts and cooperation of Ukraine with the Alliance, when on February 8 Ukraine signed the Framework Program Document, which was called "The Partnership for Peace" and the NATO presented a PfP Presentation Document on May $25^{\text {th }}$, which expressed the state of being ready to cooperate in the specific military and civilian spheres and identified a number of priority areas for the cooperation (Todorov, 2014, pp. 87-88). In March 1994, Ukraine's direct consultations with the Alliance on the formula " $16+1$ " (there 16 NATO member states and Ukraine) began. Their topics complemented and developed Kyiv-Brussels relations'principles, which were identified dur- 
ing L. Kravchuk's visit to the NATO's Headquarters, the essence of which was to recognize the political integrity and integrity of Ukraine's borders, as well as its non-nuclear status. Since 1994, Ukraine has been involved in the inception of the "Force Planning and Assessment Process" to enable it to prepare its armed forces for joint action with the NATO members, as well as to participate in the exchange of defense and budgetary planning information (the NATO-Ukraine, 2017, p. 3). In June 1995, the Alliance and the Ministry of Foreign Affairs of Ukraine exchanged letters, outlining the main objectives of the first Individual Partnership Program (IPA-95) between Kyiv and Brussels, scheduled for 1996 - 1998. The joint statement of both parties issued in the $14^{\text {th }}$ of September in 1995, formally endorsed at a special meeting of the Alliance's North Atlantic Council, facilitated the deepening of Ukraine's relations with the NATO effectively and formed the basis for formal bilateral talks on March 20, 1997 to formalize a special partnership between Ukraine and the Alliance (Burdyak, Moroz, 2008). In the future, the cooperation deepened on a mutually beneficial basis, with Ukraine participating in NATO-led peacekeeping and crisis management.

It is worth distinguishing the 1996 year, which was also characterized by an active and effective foreign policy activity of Ukraine in securing national interests in relations with the NATO in the context of strengthening relations, the non-deployment of nuclear weapons in the territory of the new members of the North Atlantic Treaty Organization. On December 10, 1996, most of Ukraine's enlargement proposals concerning the NATO-Ukraine relations were reflected in the Final Communication of the North Atlantic Council meeting at the level of foreign ministers, and the creation of the Alliance Information Center in Ukraine was confirmed (the NATO-Ukraine, 2017, p. 3).

Since 1997, the NATO-Ukraine relations reached a new level. On July 9, 1996 at the Alliance Summit in Madrid, the Head of the Ukrainian State L. Kuchma and the Heads of State and Government signed the "Charter on a Distinctive Partnership between the North Atlantic Treaty Organization and Ukraine" (Charter, 1997), which remains to this day the basic document that defines Ukraine - the NATO relations priorities. The document outlines the highest-level commitments of both sides to develop a special and effective partnership and cooperation that will enable the greater stability and shared democratic values in Central and Eastern Europe (CEE), as well as becoming the legal basis for the NATO-Ukraine consultations in the Euro-Atlantic continuum of security conflict, crisis management, peacekeeping and humanitarian operations (Charter, 1997). The Charter endorsed the principles and tools for enhancing Ukraine-NATO cooperation, defined the topics of consultations and areas of cooperation that would ensure the stability and protection of pan-European democratic values. In particular, for the successful development of relations between Ukraine and the Alliance and the resolution of the Charter's objectives, the NATO-Ukraine Commission (NUC) Forum was set up, within which the Joint Working Groups (JWGs) on military reform, arms, economic security, emergency planning, science and environmental protection, and ways to improve cooperation. According to the Ukrainian scientist I. Todorov, "this advisory mechanism of the NATO-Ukraine Commission was one of the main achievements of the Charter, as well as of all cooperation between Ukraine and the NATO. It provided the theoretical opportunity for Ukraine to consult with the NATO as soon as an external threat escalates at any time when Ukraine feels such a danger"(Todorov, 2014). The designated commission had to meet at least twice a year to mutually monitor the implementation of the NATO-Ukraine Distinctive Partnership Charter. Time has confirmed that the NATO-Ukraine Commission has proven to be an effective body. 
An important act in the development of the NATO-Ukraine relations was the opening of a Ukrainian mission in the Alliance on 7 May 1997, and in the same year in the North Atlantic Treaty Information and Documentation Center (NICD) in Kyiv. The NATO Information and Documentation Center organized the research, funded the implementation of the projects, disseminated documents and publications on the practical benefits of the NATO-Ukraine cooperation. It should be emphasized that our country was the first in the post-Soviet space to open a similar institution. A Memorandum of Understanding on Civil Emergency Planning and Disaster Preparedness was adopted at the end of 1997 to strengthen Ukraine-NATO relations, and in 1998 Distinctive Partnership Charter Implementation Plan was adopted.

The second stage of the NATO-Ukraine relations in $1998-2000$ is characterized by the political dialogue continuation between the two parties, the search for new forms and ways of cooperation between Ukraine and the NATO within the framework of the Euro-Atlantic Partnership Council in accordance with its 1998-2000 Action Plan, which was adopted for the development of a more effective and a more practical partnership, based on proposals from Member States and Alliance Partner countries, anticipated international relations activities (training courses, seminars, conferences, workshops, expert meetings, etc.) by industries. According to the Individual Partnership Program between Ukraine and the NATO, the Armed Forces were involved in 369 events in 1998 - 2000, including 38 military exercises under the Partnership for Peace Programme (PfP), 7 of which were the following "Peace Shield", "Sea Breeze" and "The Cossack's Steppe - 2000", Etc. (Participation, 2014, pp. 72-73). A new phase began in relations between Ukraine and NATO, with the establishment of the Joint Working Group on Defense Reform in 1998 and the opening of the NATO Liaison Office in Ukraine in April next year,which was aimed at establishing contacts and cooperation between Ukrainian state institutions, ministries and agencies with the relevant structures of the Alliance and its member countries. The Office promoted the reform of the defense sector in Ukraine and its participation in the Partnership for Peace.

In order to modernize the bilateral agreements with the Alliance in Ukraine, several exceptionally important legislative acts were adopted, in particular: at the end of 1998, the President of Ukraine L. Kuchma approved the State Program of Cooperation of Ukraine with the North Atlantic Treaty Organization for the period up to 2001 (State Program, 1998), On April 23, 1999, the Ukrainian Parliament approved a resolution "On relations between Ukraine and the North Atlantic Treaty Organization (NATO)", both documents stated that Ukraine's strategic goal was a full-scale and the Integration of European and the Euro-Atlantic structures and full participation in the European security system. The state program was aimed not only at intensifying cooperation in political and military spheres, but also in military-technical and scientific-technical directions, civil emergency planning, joint fight against nuclear proliferation, international terrorism, environmental protection, space sharing etc. (State Program, 1998).

During the second stage of the NATO-Ukraine relationship, working and official visits of the Alliance's representatives to Ukraine and, conversely, of Ukrainian high-ranking officials took place in Brussels. For example, on 25-28 June 1998, an Alliance delegation led by the NATO Assistant Secretary General for Political Affairs K.-P. Kleiber; on June 29-30 the first visit of the NATO-Ukraine WGG experts on military reform to Kyiv was held; On July 8-9, 1998, at the invitation of the Head of the Ukrainian State, L. Kuchma, on the occasion of the first anniversary of the signing of the Charter on a Distinctive Partnership between Ukraine and the NATO, the NATO Secretary General Kh. Solana arrived on an official visit; On April 24, 
1999, at the Summit of Heads of State and Government of the Alliance in Washington, the President of Ukraine L. Kuchma participated in the first meeting of the NATO-Ukraine Summit, etc. Similar visits by official figures of Ukraine and the NATO certainly provided a new powerful impetus for the partnership with the North Atlantic Treaty Organization laid strong foundations for bringing Ukraine and the Alliance closer to addressing European security issues.

The third stage of Ukraine-NATO relations $(2001$ - 2004) is characterized by variable intensity of the political contacts, pragmatic, concrete content in the Charter of a Distinctive Partnership between Ukraine and the Alliance, ascending dynamics up to the middle of 2004, when the progress towards the NATO was rolled up. At that time, the NATO course was also removed from the Military Doctrine, and later Ukraine lost the opportunity to participate in the Membership Action Plan (MAP). It should be mentioned that the above-mentioned situation happened in the summer of 2004, and already in the autumn the country was experiencing the first Maidan (Torba, 2016).

It should be noted that after the Ukrainian independence, being in a state of reform, was doomed to permanent adjustments to its foreign policy. However, even in such a situation, the movement to the NATO has not stopped. At the beginning of 2000, significant events took place in Ukraine's relations with the North Atlantic Alliance. For example, for the first time in a half-century of the NATO history, the members of its Political Council, led by Secretary-General Lord J. Robertson, have arrived on an official visit to strengthen a special partnership between Ukraine and the NATO and to develop a new concept of the bilateral relations for the future, security in the Euro-Atlantic area, and the Euro-Atlantic security cooperation in the framework of peacekeeping operations in the Balkans (Ukraine - NATO, 2017 , p. 5). In this regard, we will single out the $16^{\text {th }}$ meeting of the NATO-Ukraine Commission, which took place in Kyiv on 1 March 2000 at the Ambassador level. It was the first such event in Ukraine and the first meeting of the NATO Alliance outside the Allies. The NUC acknowledged the strategic nature of the NATO-Ukraine relations and endorsed our country's consistent efforts to develop closer ties with the Alliance (NATO-Ukraine, 2017, p. 5).

In order to improve the existing information base and coordinate partnership efforts, the Ukrainian Parliament ratified the "Agreement between States Parties to the North Atlantic Treaty and other States participating in the PfP Program on the status of their armed forces and the Additional Protocols" and the Additional Protocols the "Treaty on Open Skies" (2.03.2000) was adopted, making an important contribution to the transparency of the arms control issues and improving early detection and appropriate crisis management (the NATO-Ukraine, 2017, p. 5). In January 2001, the President of Ukraine L. Kuchma approved the State Program of Cooperation of Ukraine with the NATO for 2001 - 2004. Such programs of cooperation with the Alliance were available only to the states directly invited to the NATO membership, which testified to the special nature of relations between Ukraine and the North Atlantic Treaty. To assist in the implementation of the tasks identified in the Program, the Institute of National Coordinators of Ukraine-NATO Cooperation was established. The coordinators undertook cooperative activities with the Alliance in their respective fields. The following year, the State Council for the European and the Euro-Atlantic integration of our country and the realization of strategic goals of state policy for joining the Euro-Atlantic space were created.

An important step in this direction was the adoption of the NATO-Ukraine Action Plan in Prague, which aimed at achieving full integration into the Euro-Atlantic security 
structures (the NATO-Ukraine, 2017, p. 6) and the NSDC Ukraine's on May 29, 2002 political decision to acquire Ukraine. in the perspective of full NATO membership. The Ukraine's intention to integrate into the Alliance structures was confirmed by the Law of Ukraine "On the Basics of the National Security of Ukraine" of June 19, 2003 (Law of Ukraine, 2003). The Ukraine's aspirations to join NATO were further stated in the new version of the Military Doctrine of Ukraine, approved by the Decree of the President of Ukraine on June 15, 2004. The doctrine stated that "Activation of Ukraine's Euro-Atlantic integration with a focus on the NATO accession as a basis for a pan-European security system the profound reform of the state's defense sphere in accordance with the European standards is one of the most important priorities of both foreign and domestic policy" (Military Doctrine, 2004, p. 3). It is worth noting that since Ukraine first openly announced its goal of becoming a member of the Alliance since May 23, 2002, Kyiv has been moving toward the Euro-Atlantic direction overcoming obstacles. It was then that Ukraine was close to signing the NATO Membership Action Plan 9(MAP). But on 29 June 2004, the Istanbul Summit, in view of its critical attitude to Ukraine's internal political processes, did not decide to engage in formal programs for Ukraine's membership in the Alliance. In addition, under pressure from the Russian Federation, the President of Ukraine L. Kuchma made a reversal from the NATO, eliminating the above-mentioned thesis about Ukraine's accession to the North Atlantic Treaty Organization (Kapsamun, Rudenko, 2017, p. 4). It took a few more years for our country to start working on full NATO membership again.

According to the authors, during the next, the fourth stage of the NATO-Ukraine relations, the Ukrainian-NATO cooperation after the "Orange Revolution" and under President Viktor Yushchenko took on a new format. This period is characterized by significant activation, enhancement and acceleration of Ukraine's integration with the Alliance, especially within the framework of the PfP Individual Program and the Intensified Political Dialogue on Ukraine's NATO Membership launched at the NUC meeting in Vilnius on April 21, 2005, who showed willingness to join the NATO and pursued appropriate reforms. The practical discussions on approaches to the NATO accession in the context of the dialogue took place during the visit of the NATO delegation to Ukraine, led by the NATO Secretary General J. Scheffer, in October of the $18^{\text {th }}-20^{\text {th }}$ in 2005 . Within the framework of this event, the Ministry of Foreign Affairs held a meeting of the NUC at the level of ambassadors and with the participation of the Ministers of Foreign Affairs and Defense of Ukraine, and for the first time in the history of the NATO-Ukraine relations, a joint meeting of South Africa - NSDCU chaired by the President of Ukraine. A program to strengthen Ukraine's Euro-Atlantic integration with the Alliance, support for reform priorities with a focus on accession to the North Atlantic Treaty, was agreed, thus confirming the country's Euro-Atlantic course. In pursuit of these goals, the Presidential Decree of December 27, 2005, which entered into force the NSDC decision of 25 November 2005, “On Immediate Measures to Further Develop Ukraine's Relations with the North Atlantic Treaty Organization (NATO)" (Ukraine - NATO, 2017, p. 9). With this decree, V. Yushchenko reaffirmed the irreversibility of Ukraine's membership in the NATO, instructed the Cabinet of Ministers to set up an Interdepartmental Commission to prepare Ukraine for accession to the Alliance, giving it broad powers to set up working groups on specific areas of Ukraine-NATO cooperation headed by relevant national coordinators , military, information, security and other fields. In the context of the development of Ukraine's relations with the NATO, V. Yushchenko signed Decree No. 215/2006 "On the National Coordination System of Ukraine's Co-operation with the North Atlantic Treaty Organization”, 
Decree No. 295/2006 "On Approval of the NATO-Ukraine Target Plan under the NATO-Ukraine Action Plan”, which defines cooperation measures and the growth of the dynamics of political dialogue and practical cooperation.

During the following years, the Alliance actively engaged in political dialogue with Ukraine and announced an open door policy on Ukraine's accession, considering deepening cooperation with Ukraine, defining the role and place of the state in today's European security system, combating terrorism and maintaining peace and stability together with the NATO's response forces. At the Bucharest Summit in 2008, the Heads of State and Government of the NATO member states endorsed a Declaration assuring Ukraine (and Georgia) of future NATO membership (Bucharest Summit, 2008). The NATO Anniversary Summit, April 3 - 4, 2009 in Strasbourg and Kelly confirmed the NATO's intention to continue its Open Door Policy and the Bucharest Summit on Ukraine and its MAP for the NATO (Ukraine-NATO, 2017). In 2009, the Declaration on the amendment of the Charter on a Distinctive Partnership between Ukraine and the NATO was signed, which remains the main document in cooperation to this day (Declaration, 2009). It reflected the positive changes that have been made in recent years in the relationship between them, as well as securing a leading role for the NUC in the implementation of the process launched at the NATO Bucharest Summit in 2008. A landmark in the NATO-Ukraine relations is the December 4, 2009 decision, which publicized Ukraine's implementation of its first Annual National Program for 2009 to prepare Ukraine for membership in the Alliance. The document, outlining priority areas for further cooperation, reaffirmed the Allies' commitment to Ukraine's future the NATO membership and their willingness to facilitate relevant reforms in our country (NATO-Ukraine, 2017, p. 11).

Finally, the fifth stage of Ukraine-NATO relations covers 2010 - 2019. It should highlighted that the problem of Ukrainian-NATO relations, as evidenced by the recent history of Ukraine's independence day, is strongly linked to the dynamics of the development of internal political life. In 2010, Viktor Yanukovych won the anti-NATO rhetoric, dissolved the Interagency Commission on Preparing Ukraine for the NATO Accession, abolished the National Center for Euro-Atlantic Integration, and defined the non-aligned status of Ukraine and the Law on Main Domestic and Foreign Policy of Ukraine. thus, the formula for Ukrainees accession to the Alliance was removed (Law of Ukraine, 2010). This led to a weakening of Ukraine's political dialogue with the North Atlantic Treaty Organization. And only in December 2014 did the Verkhovna Rada endorse the bill on non-aligned status initiated by the President of Ukraine P. Poroshenko (Ukraine, 2014). Since then, the cooperation with the Alliance has gained new ground and has grown significantly. And as a result of the Russia-Ukrainian War, the NATO-Ukraine cooperation intensified since 2014. In the future, the cooperation continued to deepen on a mutually beneficial basis, with Ukraine actively participating in the NATO-sponsored peacekeeping operations and missions. The Alliance attached paramount importance to supporting radical changes in the security and defense field in Ukraine that played a crucial role in Ukraine's democratic development and strengthening its ability to provide national security and defense, and the transition of the Armed Forces to Alliance standards. A key systematic document for the development of cooperation with the NATO and an important tool for implementing relevant reforms with the support of the Alliance have been the Ukraine-NATO Annual National Cooperation Programs (RNPs), which have been developed since 2009 and approved by the relevant decree of the President of Ukraine. The implementation of the RNP helped Ukraine become one step closer to the NATO standards, enhanced systematic synergy with the Alliance, drawing on the NA- 
TO's expert, financial, logistical and other capabilities to strengthen Ukraine's defense capabilities and counteract long-term Russian aggression (Romanyuk, 2017, p. 3). During the 2010 - 2019 implementation of the RNP, a series of practical consultations were held with the Alliance experts in support of Ukraine, increasing its status as a country that makes every possible effort to strengthen security in the world, and consistent implementation of international obligations.

At the same time, the development of the strategic partnership of Ukraine with the Alliance, in accordance with the principles set out in the Charter on a Distinctive Partnership between Ukraine and the Alliance, the Declaration on its Supplement and the Practical Activity of the Commission, has increasingly become a priority national interest of Ukraine in the sphere of international activity. The NATO at the level of Heads of State and Government on enhancing security and defense cooperation in line with the NATO standards, implementing measures to support the countries in the face of unprecedented aggression and hybrid war started by Russia.

In the context of Ukraine's relations with the NATO transformation on the highest-level the following measures were taken: decisions on the creation of a new National Security Strategy for Ukraine were made; the systematic control over the security and defense sector of Ukraine was approved; the modernization of the system of Ukraine-NATO cooperation's coordination was endored; the increasing efficiency in the preparation and implementation of annual national programs were agreed; the creating conditions for thw interoperability and shared capabilities with the NATO were aproved as well as the the use of the NATO standards in the military field.

Such a systematic approach in Ukraine's relations with the Alliance made the process of Ukraine's accession to the Euro-Atlantic community effective and practical. In June 2017, the Verkhovna Rada of Ukraine passed a law reopening one of the cornerstones of national foreign and security policy, making our country's NATO a strategic foreign policy priority, and on February 7, 2019, the NATO membership was enshrined in the Constitution of Ukraine, thereby acquiring a legitimate character. Russia's aggression against Ukraine has virtually eliminated arguments from the backers of multi-vector, equal distance and neutrality. Unambiguous recognition of Ukraine's future membership in the organization, the need for which is an indisputable imperative of the time.

The Conclusions. The NATO-Ukraine relations have come a long way from the Special Partnership Charter, the Action Plan, the Intensified Dialogue on Membership, and others. documents that have generated significant versatile potential for the Euro-Atlantic choices. The NATO and Ukraine have a long history of mutual relations, from multi-vector and neutrality to accelerated integration and constitutional consolidation of Ukraine's accession to the North Atlantic Treaty Organization. Characteristic of Ukraine-NATO cooperation is the process of its structural modernization and intensification of political dialogue in the political and military spheres. Under current conditions, the NATO-Ukraine relations play an important role in enhancing Ukraine's defense capability to counter the Russian aggression, will help strengthen national security, reform the armed forces by the NATO standards, and create the foundations for Ukraine's democratic development. Ukraine's further movement to the NATO appears to be an alternative in today's international and regional security environment. The acceleration of Ukraine's emergence as a full-fledged component of the EuroAtlantic civilization and its promotion to the NATO membership depends on the political will of the new political generation and Ukrainian society. 
Acknowledgments. The authors are grateful to the staff of the Institute of History of Ukraine and World History of the National Academy of Sciences of Ukraine, as well as to the members of the editorial board of the Eastern European Historical Bulletin for providing advice on the preparation of the article for printing.

Financing. The authors received no financial support for the proposed work, authorship, and publication of this article.

\section{BIBLIOGRAPHY}

Aleksiievets, L. \& Pryidun, S. (2012). Ukraina v systemi mizhnarodnykh vidnosyn: deiaki osoblyvosti i problemy $(1991-2011)$ [Ukraine in the system of international affairs: some features and problems (1991 - 2011)]. Ukraina - Yevropa - Svit. Mizhnarodnyi zbirnyk naukovykh prats. Seria: Istoria, mizhnarodni vidnosyny, 10, 179-183. [in Ukrainian]

Aleksiievets, M. \& Seko, Ya. (2016). Zovnishnia polityka Ukrainy: vid bahatovektornosti do bezalternatyvnosti [Ukraine's foreign policy: from multidirectional to no alternative]. Ukraina Yevropa - Svit. Mizhnarodnyi zbirnyk naukovykh prats. Seria: Istoria, mizhnarodni vidnosyny. Vyp. 17: 25-ii richnytsi Nezalezhnosti Ukrainy prysviacheno, 34-49. [in Ukrainian]

Boietskyi, T. (2006). Dotsilnist vstupu Ukrainy do NATO [Feasibility of Ukraine's accession to NATO]. Ekonomichnyi chasopys - XXI, 9-10, 8-9. [in Ukrainian]

Brzezinski, Z. (2006). Ukraina $v$ heostratehichnomu konteksti [Ukraine in geostrategic context]. Kyiv: Vydavnychyi dim "Kyievo-Mohylyanska Akademia", 101 s. [in Ukrainian]

Bukharestskyi samit. (2008). Bukharestskyi samit NATO zavershyvsia [Bucharest Summit of NATO is over]. URL: http://maidan.org.ua/arch2008/1207231649.html. [in Ukrainian]

Burdiak, V. \& Moroz, I. (2008). Perspektyvy spivrobitnytstva "Ukraina - NATO" i rol u tsomu polskoho faktora [Prospects of Ukraine-NATO cooperation and role of Polish factor in this]. URL: http://nbuv.gov.ua/UJRN/PoMe_2008_3_17. [in Ukrainian]

Chekalenko, L. (2011). Zovnishnia polityka Ukrainy [Foreign policy of Ukraine]. Kyiv: Kondor, 290 p. [in Ukrainian]

Chernousenko, O. (2003). Partnerstvo Ukraina - NATO: evoliutsia rozvytku [Ukraine-NATO partnership: the evolution of development]. Polityka i chas, 10, 18-27. [in Ukrainian]

Deklaratsia. (1990). Deklaratsia pro derzhavnyi suverenitet Ukrainy [Declaration of State Sovereignty of Ukraine]. Vidomosti Verkhovnoi Rady Ukrainy, 31, 429. URL: https://zakon.rada.gov. ua/laws/show/55-12. [in Ukrainian]

Deklaratsia. (2009). Deklaratsia pro dopovnennia do Khartii pro osoblyve partnerstvo Ukrainy i NATO [Declaration on Complement to the Charter on a Distinctive Partnership]. https://zakon.rada. gov.ua/laws/show/950_021. [in Ukrainian]

Derzhavna prohrama. (1998). Derzhavna prohrama spivrobitnytstva Ukrainy z Orhanizatsiieiu Pivnichnoatlantychnoho dohovoru na period do 2001 roku. Zatverdzheno Ukazom Prezydenta Ukrainy vid 4 lystopada 1998 r. № 1209/98 [State Program of Cooperation of Ukraine with the North Atlantic Treaty Organization for the period to 2001. Approved by the Decree of the President of Ukraine of November 4, 1998 № 1209/98.]. In Zovnishnia polityka Ukrainy: Khrestomatia. Chastyna persha (pp. 290-314). Kyiv. [in Ukrainian]

Dzherdzh, S. (2006). Bezpidstavnist mifiv shchodo NATO ta shliakhy yikh podolannia v konteksti yevropeiskoho dosvidu [Groundlessness of myths about NATO and ways to overcome them in the context of European experience]. Ekonomichnyi chasopys - XXI, 1-2, 38-39. [in Ukrainian]

Fukuyama, F. (2019). Politychnyi poriadok $i$ politychnyi zanepad. Vid promyslovoi revoliutsii do hlobalizatsii demokratii [Political order and political decay: from the industrial revolution to the globalization of democracy]. Kyiv: Nash format, 608 p. [in Ukrainian]

Halchynskyi, A. (2002). Ukraina - na perekhresti heopolitychnykh interesiv [Ukraine at the crossroads of geopolitical interests]. Kyiv: Znannia Ukrainy, 180 p. [in Ukrainian]

Horbulin, V. (2009). Plan dii Ukraina - NATO: dosiahnennia i problemy [Ukraine-NATO Action Plan: Achievements and Problems]. Ukraina - NATO, 1, 5-17. [in Ukrainian] 
Ivchenko, O. (1997). Ukraina v systemi mizhnarodnykh vidnosyn: istorychna retrospektyva ta suchasnyi stan [Ukraine in the system of international affairs: historical retrospective and current condition]. Kyiv: "RITS UANNP", 688 p. [in Ukrainian]

Kapsamun, I., Rudenko, A. \& Torba, V. (2017). 276. Den, 97-98, 4. [in Ukrainian]

Khartia (1997). Khartia pro osoblyve partnerstvo mizh Ukrainoiu ta Orhanizatsiieiu PivnichnoAtlantychnoho dohovoru [Charter on a special partnership between Ukraine and the North Atlantic Treaty Organization]. URL: https://zakon3.rada.gov.ua/laws/show/994_002. [in Ukrainian]

Kudriachenko, A. (2009). Yevroatlantychnyi postup Ukrainy ta yii vidnosyny z Rosiieiu [EuroAtlantic Development of Ukraine and its relations with Russia.]. Ukraina dyplomatychna. Naukovyi shchorichnyk, 10, 772-786. [in Ukrainian]

Lepiavko, S. \& Mahomedov, A. (2018). Spivrobitnytstvo u viyskoviy sferi, yak pryklad praktychnoi vzaiemodii na rivni "Ukraina - NATO" v ploshchyni realnykh viyskovykh zahroz [Cooperation in the military sphere as an example of practical cooperation at the Ukraine - NATO level in the plane of real military threats]. Molodyi vchenyi, 6, 60-63. [in Ukrainian]

Lukas, E. (2009). Nova kholodna viina. Yak Kreml zahrozhuie i Rosii, i Zakhodu [How the Kremlin Menaces both Russia and the West]. Kyiv: Tempora, 488 p. [in Ukrainian]

Marchuk, Ye. (2016). Na shliakhu do NATO [On the way to NATO]. Kyiv: Kyiv - Paryzh - Dakar, 608 p. [in Ukrainian]

Martynov, A. (2017). Vidnosyny Yevrosoiuzu i NATO: istorychni uroky [Realations between European Union and NATO: historical lessons]. Ukraina - Yevropa - Svit. Mizhnarodnyi zbirnyk naukovykh prats. Seria: Istoria, mizhnarodni vidnosyny, 17, 191-201. [in Ukrainian]

Perepelytsia, H. (2009). Ukraina i novi vyklyky u sferi bezpeky [Ukraine and new challenges in security sphere]. Ukraina dyplomatychna. Naukovyi shchorichnyk, 10, 681-702. [in Ukrainian]

Perepelytsia, H. (2002). Ukraina na shliakhu do NATO: cherez radykalni reformy do nabuttia chlenstva [Ukraine on the way to NATO: through radical reforms to membership] / Za zah. red. H. M. Perepelytsi. Kyiv: VD "Stylos", 400 p. [in Ukrainian]

Poliakov, L. (2007). Ukraina - NATO 10 rokiv spivrobitnytstva v imia bezpeky ta myru [UkraineNATO 10 years of cooperation in the name of security and peace]. Viysko Ukrainy, 7, 6-9. [in Ukrainian]

Pryidun, S. (2017). Istoryko-heopolitychni peredumovy ta osnovni etapy formuvannia zovnishnopolitychnoi dialnosti Ukrainy [Historical and geopolitical background and main stages of Ukraine's foreign policy formation]. Ukraina - Yevropa - Svit. Mizhnarodnyi zbirnyk naukovykh prats. Seria: Istoria, mizhnarodni vidnosyny, 19, 79-90. [in Ukrainian]

Romaniuk, N. (2017). Suchasnyi stan ta osoblyvosti spivrobitnytstva Ukrainy z NATO. Aktualni problemy krainoznavchoi nauky [Modern state and features of Ukraine - NATO cooperation. Actual problems of country studies science]. URL: https://internationalconference2014.wordpress.com/2017/05/26

Soskin, O. (Ed.) (2007). Partnerstvo zarady bezpeky: dosvid krain NATO ta ukrainska perspektyva? [Partnership for security: experience of NATO countries and Ukrainian perspective?]. Kyiv: Vyd-vo "Instytut transformatsii suspilstva", 336 p. [in Ukrainian]

Soskin, O. (Ed.) (2008). Vstup do NATO - stratehichnyi vybir Ukrainy [NATO membership strategic choice of Ukraine]. Kyiv: Vyd-vo "Instytut transformatsii suspilstva", 192 p. [in Ukrainian]

Todorov, I. (2006). Ukraina na shliakhu do yevropeiskoi ta yevroatlantychnoi spilnoty [Ukraine on the way to the European and Euro-Atlantic community]. Donetsk, 268 p. [in Ukrainian]

Todorov, I. (2014). Istorychni, heopolitychni ta polityko-pravovi zasady spivrobitnytstva Ukrainy i NATO [Historical, geopolitical and political and legal principles of cooperation between Ukraine and NATO]. Nezalezhnyi kulturolohichnyi chasopys, 77, 84-108. [in Ukrainian].

Torba, V. (2016). Khto sabotuie rukh do NATO? [Who sabotages the movement towards NATO?]. Den, 19-20, 5. [in Ukrainian]

Uchast. (2014). Uchast Zbroinykh syl Ukrainy u prohrami "Partnerstvo zarady myru" [Participation of the Armed Forces of Ukraine in the Partnership for Peace Program]. Nezalezhnyi kulturolohichnyi chasopys "YI", 77, 68-73. [in Ukrainian]

Ukraina - NATO. (2017). Ukraina-NATO. Khronolohia vidnosyn. [Ukraine-NATO. Chronology of relations]. URL: https://ukraine-nato.mfa.gov.ua/ua/ukraine-nato/relations. [in Ukrainian] 
Ukraina. (2014). Ukraina vidmovylasia vid pozablokovoho statusu [Ukraine abandoned a nonaligned status]. https://www.pravda.com.ua/news/2014/12/23/7052990/.[in Ukrainian]

Vidnianskyi, S. (2011). Nezalezhna Ukraina: dvadtsiat rokiv mizh Yevropoiu ta Yevraziieiu [Independent Ukraine: twenty years between Europe and Eurasia]. Ukraina - Yevropa - Svit. Mizhnarodnyi zbirnyk naukovykh prats. Seria: Istoria, mizhnarodni vidnosyny, 6-7, 24-38. [in Ukrainian]

Vlasiuk, O. (2008). Ukraina - NATO: suchasnyi stan vidnosyn ta perspektyva rozvytku [Ukraine - NATO: the current state of relations and the prospect of development] / Za zah. red. O. S. Vlasiuka, Kyiv: PTS “Foliant”, 352 p. [in Ukrainian]

Voienna doktryna. (2004). Voienna doktryna Ukrainy [Military Doctrine of Ukraine]. Narodna armia, 116, 3-5. [in Ukrainian]

Zakon Ukrainy. (2003). Zakon Ukrainy "Pro osnovy natsionalnoyi bezpeky Ukrainy" [On the Fundamentals of National Security of Ukraine]. Uriadovyi kurier, 17, 1-3. [in Ukrainian]

Zakon Ukrainy. (2010). Zakon Ukrainy pro osnovni napriamky vnutrishnoi i zovnishnoi polityky [The Law of Ukraine "On the Foundations of Domestic and Foreign Policy"]. URL: https://zakon3.rada.gov.ua/laws/show/2411-17. [in Ukrainian]

Zlenko, A. (2001). Zovnishnia polityka Ukrainy: vid romantyzmu do prahmatyzmu: vystupy. Promovy. Interviu. Statti [Foreign Policy of Ukraine: From Romanticism to Pragmatism: Speeches. Public Speeches. Interviews. Articles]. Comp. K. P. Yelisieiev. Kyiv: Presa Ukrainy, 2001, 370 p. [in Ukrainian]

Zuiko, O. (2006). Osnovni priorytety yevroatlantychnoi intehratsii Ukrainy [Main priorities of Euro-Atlantic integration of Ukraine]. Ekonomichnyi chasopys - XXI, 9-10, 10-11. [in Ukrainian]

The article was received on July 12, 2019. Article recommended for publishing 26/02/2020. 